\title{
A molecular method for the detection of sally lightfoot crab larvae (Grapsus grapsus, Brachyura, Grapsidae) in plankton samples
}

\author{
Patrícia R. Ströher ${ }^{1}$, Carina R. Firkowski ${ }^{1}$, Andrea S. Freire ${ }^{2}$ and Marcio R. Pie ${ }^{1}$ \\ ${ }^{1}$ Laboratório de Dinâmica Evolutiva e Sistemas Complexos, Departamento de Zoologia, \\ Universidade Federal do Paraná, Curitiba, PR, Brazil. \\ ${ }^{2}$ Centro de Ciências Biológicas, Universidade Federal de Santa Catarina, Florianópolis, SC, Brazil.
}

\begin{abstract}
The decapod Grapsus grapsus is commonly found on oceanic islands of the Pacific and Atlantic coasts of the Americas. In this study, a simple, quick and reliable method for detecting its larvae in plankton samples is described, which makes it ideal for large-scale studies of larval dispersal patterns in the species.
\end{abstract}

Key words: dispersal, aratu, sayapa, molecular marker.

Received: December 1, 2010; Accepted: March 23, 2011.

Grapsus grapsus (Linnaeus, 1758) (Brachyura: Grapsidae), commonly known as the "sally lightfoot" crab in English, "aratu" in Portuguese and "sayapa" in Spanish, occurs on the eastern Pacific continental coast and islands from Baja California to northern Chile, as well as in large numbers on the Galapagos Islands. In the Atlantic, although absent along the coast, it occurs on the Caribbean Islands, and very abundantly on the western oceanic islands, viz., Saint Paul's Rocks, the Rocas Atoll, Fernando de Noronha and Trindade. According to Hartnoll (2009), due to the occurrence of Grapsus adscensionis (Osbeck, 1765) on various East Atlantic islands, and along much of the West African coast, the status of the crabs from Trinidade Island is yet to be defined. As morphological differences are very slight (Manning and Chace Jr, 1990), according to Ratti (PhD thesis, Universidade de São Paulo, 2004), there is no justification in considering the two as distinct species (but see Guerao et al., 2001). Although available information on G. grapsus is scarce, its reproductive biology was the object of a recent study by Freire et al. 2011). Phenotypic plasticity is manifest, both in the pronounced carapace coloration pattern of G. grapsus; the red color, an important factor in mating also being associated with aggressive intra-specific behaviour, as well as the larger size of the males at sexual maturity.

The occurrence of G. grapsus on several remote oceanic islands poses intriguing questions about the demographic and genetic relationships within the species. Given the involved distances, one would expect pronounced ge-

Send correspondence to Marcio R. Pie. Laboratório de Dinâmica Evolutiva e Sistemas Complexos, Departamento de Zoologia, Universidade Federal do Paraná, Caixa Postal 19020, 81531-990 Curitiba, PR, Brazil. E-mail: pie@ ufpr.br. netic differentiation and little recruitment from alternative locations. For instance, plankton sampling using conventional methods clearly revealed G. grapsus larvae retention in the vicinity of Saint Paul's Rocks (Koettker et al., 2009). Nevertheless, external morphology among populations appears to be very similar, thereby suggesting some level of gene flow between them. Elucidating these questions necessarily requires understanding the larval biology of $G$. grapsus, especially as to timing and the distances that its larvae are capable of travelling. Traditionally, brachyuran larvae are studied by screening plankton samples for the presence of those of interest by stereoscopic microscopy. However, this approach is time-consuming and often inaccurate (Boeger et al., 2007). Methods based on molecular markers have brought important new tools to the study of the biology of planktonic larvae by facilitating their precise and rapid detection (Pie et al., 2006; Boeger et al., 2007; Pardo et al., 2009). Herein, we developed a set of specific primers for identifying G. grapsus larvae in plankton samples, whereby, irrespective of the presence of the DNA of various species in a given reaction, the designed primers will only anneal to target-species DNA.

A $803 \mathrm{bp}$ fragment of the mitochondrial control region of G. grapsus (GenBank accession number JF444484) was sequenced from specimens collected at the Fernando de Noronha archipelago (Brazil, 51 $30^{\circ}$ N, $0^{\circ} 7^{\prime} \mathrm{W}$ ). Total genomic DNA was extracted from a muscle sample using the EZ-DNA kit (Biosystems, Brazil), according to manufacturer's instructions. The fragment was amplified using primers dlussaf1 (5'-GTATAACCGCGAATGCTGGCA C-3') and ileucar2 (5' -CCTTTTAAATCAGGCACTATA -3') (Oliveira-Neto et al., 2007), with the following PCR protocol: $5 \mathrm{~min}$ at $95{ }^{\circ} \mathrm{C}, 35$ cycles of $92{ }^{\circ} \mathrm{C}$ for $30 \mathrm{~s}$, 
$48-51^{\circ} \mathrm{C}$ for $30 \mathrm{~s}$ and $68^{\circ} \mathrm{C}$ for 30 , followed by final extension at $68{ }^{\circ} \mathrm{C}$ for $2 \mathrm{~min}$. Reactions were done in $25 \mu \mathrm{L}$ reactions with 1.25 units of AmpliTaq DNA polymerase, 1X PCR buffer, $2 \mathrm{mM}$ of $\mathrm{MgCl}_{2}, 0.4 \mathrm{mM}$ of dNTPs and $0.5-1 \mu \mathrm{M}$ of each primer. Unique regions were identified by comparing the G. grapsus sequence with the same region in two other brachyuran species: Ucides cordatus (Linnaeus, 1763) (Ocypodidae) and Cardisoma guanhumi Latreille, 1825 (Gecarcinidae), to date the only closely related species in which sequencing had been undertaken (Pie et al., 2008). The lack of similarity furnished ample proof of propriety for developing species-specific primers. Of the four thus developed, the best set in terms of sensitivity and accuracy was used in further analyses, namely Dlussaf1 (5'GTATAACCGCGAATGCTGGCAC-3') and Grapsus.R1 (5'-CCCTTCTCTTTTTCTTTGGGATG-3'), thereby generating a $401 \mathrm{bp}$ fragment. In addition, a second primer pair was used in the same reaction to amplify a $\approx 540$-bp region of the $16 \mathrm{~S}$ ribosomal gene to serve as positive control (16SL, 5'-CGCCTGTTTATCAAAAACAT-3' and 16SH, 5'-CCGGTCTGAACTCAGATCACGT-3') (Palumbi et al., 1991). Thus, given that $16 \mathrm{~S}$ primers are universal, $\mathrm{PCR}$ amplification of a sample of plankton that lacked $G$. grapsus would only generate the $16 \mathrm{~S}$ band, and not the specific. The PCR protocol to obtain specific bands consisted of $4 \mathrm{~min}$ at $94{ }^{\circ} \mathrm{C}, 32$ cycles of $94{ }^{\circ} \mathrm{C}$ for $30 \mathrm{~s}, 58.2{ }^{\circ} \mathrm{C}$ for $30 \mathrm{~s}$ and $70^{\circ} \mathrm{C}$ for $60 \mathrm{~s}$, followed by final extension at $70^{\circ} \mathrm{C}$ for $3 \mathrm{~min}$, all done in $25 \mu \mathrm{L}$ reactions with 0.625 units of AmpliTaq DNA polymerase, 1X PCR buffer, $1.5 \mathrm{mM}$ of $\mathrm{MgCl}_{2}$, and $0.5 \mathrm{mM}$ of dNTPs. Primer concentrations for the $16 \mathrm{~S}$ and control region primers were 0.8 and $4 \mu \mathrm{M}$, respectively. PCR products were electrophoresed on $2 \%$ agarose gels. Specificity tests were undertaken using four closely related crab species: Goniopsis cruentata (Latreille, 1803) (Grapsidae), Ocypode quadrata (Fabricius, 1787) (Ocypodidae), Cardisoma guanhumi (Grapsoidea, Gecarcinidae), and Ucides cordatus (Ocypodidae). In addition, sensitivity tests were carried out with increasingly smaller concentrations of template DNA (300 ng, $30 \mathrm{ng}, 3 \mathrm{ng}, 0.3$, $0.03 \mathrm{ng}$ ) to determine detection limits of the method.

The very sensitive method thus developed was capable of detecting DNA amounts as low as $0.03 \mathrm{ng}$ (Figure 1). Notably, an extraction from a single larva of a planktonic species often provides twice as much DNA (e.g. Pie et al., 2006). Moreover, in amplifications using the specific primers, the specific band was consistently detected in $G$. grapsus samples, but not so when using DNA from other species (Figure. 2). DNA performance was similar in additional tests (not shown) using known concentrations of environmental plankton samples and increasingly smaller amounts of G. grapsus, a sure indication of the utility of this primer for investigating patterns of larval occurrence of $G$. grapsus in the field. Moreover, the combination of extensive field collections and automated procedures for DNA extraction and amplification, is a potential means of obtain-

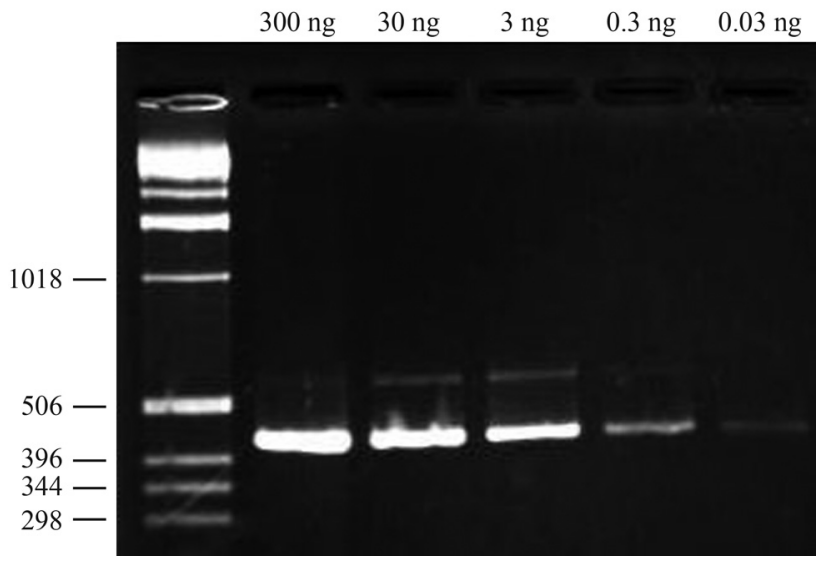

Figure 1 - Sensitivity tests of the molecular protocol developed in the present study to detect larvae of Grapsus grapsus, including the amplification of $\mathrm{a} \approx 540$-bp region In the $16 \mathrm{~S}$ ribosomal gene that served as a positive control, and the $401 \mathrm{bp}$ fragment corresponding to the specific marker. Each lane received increasingly lower concentrations of template DNA from $300 \mathrm{ng}$ to $0.03 \mathrm{ng}$. See text for details.

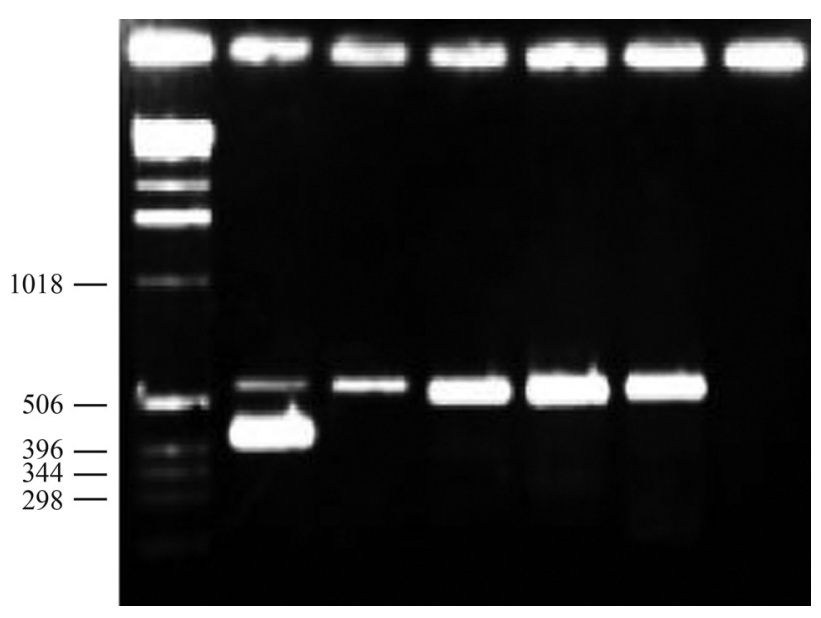

Figure 2 - Specificity tests of the molecular protocol developed in the present study to detect larvae of Grapsus grapsus, all of which including both the positive control and specific primer sets. According to the size of the marker, each lane represents the application of the molecular protocol for each species: (1) Grapsus grapsus (Grapsidae); (2) Goniopsis cruentata (Grapsidae); (3) Ocypode quadrata (Ocypodidae); (4) Cardisoma guanhumi (Gecarcinidae); (5) Ucides cordatus (Ocypodidae); (6) Negative control.

ing unprecedented high-resolution information on spatial and temporal variation in the abundance of $G$. grapsus larvae throughout its range.

\section{Acknowledgments}

This work was supported by a grant of the Conselho Nacional de Desenvolvimento Científico e Tecnológico (CNPq, 571334/2008-3) to M.R.P and the Fundação Boticário (0849/ 2009 2).

\section{References}

Boeger WA, Pie MR, Falleiros RM, Ostrensky A, Darrigran G, Mansur MCD and Belz CE (2007) Testing a molecular pro- 
tocol to monitor the presence of golden mussel larvae (Limnoperma fortunei) in plankton samples. J Plankton Res 29:1015-1019.

Freire AS, Pinheiro MAA, Karam-Silva $\mathrm{H}$ and Teschima MM (2011) Biology of Grapsus grapsus (Linnaeus, 1758) (Brachyura, Grapsidae) in the Saint Peter and Saint Paul Archipelago, Equatorial Atlantic Ocean. Helgoland Mar Res (Epub).

Guerao G, Schubart CD and Cuesta JA (2001) The first zoeal stages of Grapsus grapsus (Linnaeus) and Geograpsus lividus (H. Milne Edwards) (Decapoda, Brachyura, Grapsidae) from the Western Atlantic. Nauplius 9:111-121.

Hartnoll RG (2009) Sexual maturity and reproductive strategy of the rock crab Grapsus adscensionis (Osbeck, 1765) (Brachyura, Grapsidae) on Ascension Island. Crustac Int J Crustac Res 82:275-291.

Koettker AG, Freire S and Sumida PG (2009) Temporal, diel and spatial variability of decapod larvae from St Paul's Rocks, an equatorial oceanic island of Brazil. J Mar Biol Assoc UK 90:1227-1239.

Manning RB and Chace Jr FA (1990) Decapod and stomatopod crustacea from Ascension Island, South Atlantic Ocean. Smithson Contrib Zool 503:1-91.
Oliveira-Neto JF, Boeger WA, Pie MR, Ostrensky A and Hungria DB (2007) Genetic structure of populations of the mangrove crab Ucides cordatus (Decapoda, Ocypodidae) at local and regional scales. Hydrobiologia 583:69-76.

Palumbi SR, Martin A, Romano S, McMillan WS, Stice S and Grabowski G (1991) The Simple Fool's Guide to PCR. University of Hawaii Press, Honolulu, 45 pp.

Pardo LM, Ampuero D and Véliz D (2009) Using morphological and molecular tools to identify megalopae larvae collected in the Field: The case of sympatric Cancer crabs. J Mar Biol Assoc UK 89:481-490.

Pie MR, Boeger WA, Patella L and Falleiros RM.(2006) A fast and accurate molecular method for the detection of larvae of the golden mussel Limnoperna fortunei (Mollusca, Mytilidae) in plankton samples. J Mollusc Stud 72:218-219.

Pie MR, Oliveira-Neto JF, Boeger WA and Baggio RA (2008) The organization of the mitochondrial control region in two brachyuran crustaceans: Ucides cordatus (Ocypodidae) and Cardisoma guanhumi (Gecarcinidae). J Heredity 99:432-437.

Associate Editor: Louis Bernard Klaczko

License information: This is an open-access article distributed under the terms of the Creative Commons Attribution License, which permits unrestricted use, distribution, and reproduction in any medium, provided the original work is properly cited. 